\title{
MODEL KOMUNIKASI ORGANISASI PERANGKAT DAERAH PROVINSI SULAWESI BARAT DALAM PERENCANAAN PROGRAM PENANGGULANGAN KEMISKINAN MARASA
}

\author{
Erwin Rasyid $^{1}$, Ade Putranto Prasetyo Wijiharto Tunggali ${ }^{1}$, Moch Imron Rosyidi ${ }^{2}$ \\ ${ }^{1}$ Universitas Aisyiyah Yogyakarta, ${ }^{2}$ Universitas Muhammadiyah Magelang \\ Email: erwin.rasyid@unisayogya.ac.id
}

Diterima : 8 November 2019

Disetujui : 7 Januari 2020

Diterbitkan : 21 Februari 2020

\begin{abstract}
Abstrak
Perencanaan program penanggulangan kemiskinan di Provinsi Sulawesi Barat melibatkan koordinasi lintas sektor. Sehingga berdampak pada adanya persoalan ego sektoral dalam upaya komunikasi yang terjadi di antara unsur Organisasi Perangkat Daerah (OPD) Provinsi Sulawesi Barat. Tujuan dari penelitian ini yaitu mengidentifikasi peran, model, jalur penyebaran informasi serta hambatan komunikasi OPD Provinsi Sulawesi Barat dalam mengelola perencanaan Program Marasa. Jenis penelitian ini yaitu deskriptif kualitatif dengan menggunakan pendekatan studi kasus. Subyek penelitian ini terdiri dari unsur-unsur OPD Pemerintah Provinsi Sulawesi Barat yang terlibat dalam perencanaan Program Marasa. Hasil penelitian ini menunjukkan Relasi antar aktor dalam model komunikasi antar OPD Provinsi Sulawesi Barat membentuk dua jalur penyebaran informasi yang terdiri dari jalur formal dan informal. Pendekatan komunikasi yang bersifat formal dalam sistem komunikasi pemerintahan OPD Provinsi Sulawesi Barat justru menimbulkan berbagai macam persoalan. Mulai dari sulitnya koordinasi antar lintas sektor, keterbatasan penciptaan ruang komunikasi serta berbagai macam persoalan ego sektoral lainnya. Aktor-aktor yang terdapat di Provinsi Sulawesi Barat kemudian mensiasati hal tersebut dengan menggunakan pendekatan gaya komunikasi yang bersifat informal. Pendekatan ini sedikit banyak mampu mengurangi berbagai macam hambatan yang diakibatkan oleh proses penyebaran informasi yang bersifat formal.
\end{abstract}

Kata Kunci: Model Komunikasi; Organisasi Perangkat Daerah; Perencanaan Program; Sulawesi Barat;

\begin{abstract}
Planning for poverty alleviation programs in West Sulawesi Province involves cross-sectoral coordination. So that the impact on the existence of sectoral ego problems in communication efforts that occur among elements of the Regional Apparatus Organization (OPD) of West Sulawesi Province. The purpose of this study is to identify the role, model, path of information dissemination and communication barriers of OPD in West Sulawesi Province in managing the Marasa Program planning. This type of research is descriptive qualitative using a case study approach. The subjects of this study consisted of elements of the West Sulawesi Provincial Government OPD involved in planning the Marasa Program. The results of this study indicate that relations between actors in the communication models between West Sulawesi Province OPD form two channels of information dissemination consisting of formal and informal channels. The formal communication approach in the OPD government communication system in West Sulawesi Province raises various kinds of problems. Starting from the difficulty of inter-sectoral coordination, the limitations of the creation of communication space and various other sectoral ego problems. Actors in West Sulawesi Province then deal with this by using an informal communication style approach. This approach is more or less able to reduce various kinds of obstacles caused by the process of disseminating formal information.
\end{abstract}

Keywords: Communication Models; Program Planning; Regional Apparatus Organization; West Sulawesi; 


\section{PENDAHULUAN}

Berdasarkan data dari Badan Pusat Statistik (BPS) dan Direktorat Jenderal Otonomi Daerah Kemeterian Dalam Negeri Republik Indonesia, total daerah otonom yang terbentuk dari tahun 1999 hingga tahun 2014 sebanyak 542. Jumlah tersebut terdiri dari 34 Provinsi, 416 Kabupaten (tidak termasuk 1 kabupaten administratif di Provinisi DKI Jakarta) serta 98 Kota (tidak termasuk 5 kota administratif di Provinsi DKI Jakarta.

Dari data tersebut terlihat bahwa laju pertumbuhan daerah otonomi baru mengalami peningkatan yang sangat signifikan pasca disahkannya UU No.22 Tahun 1999. Pada tahun 1999, jumlah daerah otonom yang ada di Indonesia hanya sekitar 26 Provinsi, 268 Kabupaten dan 73 Kota. Kemudian pada tahun 2014 terjadi pertumbuhan hampir sekitar 50 persen daerah otonom di Indonesia. Namun pada tahun 2017, Pemerintah resmi mengeluarkan kebijakan moratorium terhadap pemekaran atau pembentukan daerah otonomi baru.

Desentralisasi diharapkan dapat mendorong pertumbuhan ekonomi dan pendapatan per kapita yang lebih tinggi, sehingga meningkatkan potensi untuk mengurangi kemiskinan (Cassells, 2014). Berbagai studi mengenai kemiskinan telah banyak dilakukan, namun hingga saat ini kesepahaman tentang kemiskinan masih belum dicapai secara mantap. Karenanya, upaya untuk memperkokoh kriteria dan indikator kemiskinan perlu terus dilakukan (Suharto, 2009).

Fenomena desentralisasi pembangunan yang diwujudkan dengan kebijakan pemekaran wilayah saat ini masih menimbulkan pro dan kontra dikalangan politisi, pemerintah, tokoh masyarakat maupun para pakar, akademisi dan praktisi. Hal ini tak terlepas dari adanya sikap skeptis terhadap pembentukan daerah otonomi baru (DOB) yang masih menyimpan berbagai macam persoalan. Kemendagri menyatakan bahwa hanya sekitar 30 persen DOB yang sukses meningkatkan kesejahteraan dan pelayanan pemerintah kepada masyarakat.

Sejak pendapatan nasional (GNP) mulai dijadikan indikator pembangunan tahun 1950an, para ekonom dan ilmuwan sosial selalu merujuk pada pendekatan tersebut manakala berbicara masalah kemiskinan suatu negara. Pengukuran kemiskinan kemudian sangat dipengaruhi oleh perspektif income poverty yang menggunakan pendapatan sebagai satusatunya indikator "garis kemiskinan" (Suharto, 2009). Menurut Huraerah (2013), ada beberapa kekeliruan dalam strategi kebijakan penanggulangan kemiskinan di Indonesia. Pertama, kebijakan kemiskinan di Indonesia masih berorientasi pada aspek ekonomi dari pada aspek multidimensional. Kebijakan pengentasan kemiskinan lebih bernuansa karitatif (kemurahan hati) dan tidak mengedapankan produktivitas. Maksud dari karitatif di sini adalah pemerintah masih belum bisa mendorong penduduk miskin untuk lebih mandiri.

Penyebab yang mengakibatkan kebijakan penanggulangan kemiskinan di Indonesia kurang efektif adalah karena tidak adanya sinergisme program penanggulangan kemiskinan yang terarah, terpadu, dan berkelanjutan sebagai akibat dari masih adanya ego sektoral dan tumpang tindihnya tugas pokok dan fungsi antar Satuan Kerja Perangkat Daerah (Huraerah, 2013). Selain itu, Pemerintah daerah dan DPRD dalam penyusunan, pembahasan dan penetapan APBD kurang peka terhadap penanggulangan kemiskinan dalam arti APBD tidak pro aktif (masyarakat miskin). Hal ini terlihat dari postur anggaran khususnya belanja daerah dan pembiayaan daerah relatif masih kecil kurang signifikan dalam penanggulangan 
kemiskinan (Nawawi, 2015). Jika ditinjau dari aspek ekonomi, kebijakan otonomi daerah bertujuan untuk pemberdayaan kapasitas daerah dalam meningkatkan proses pembangunan, yang pada akhirnya diharapkan dapat meningkatkan kesejahteraan masyarakat di daerah (Ahmad, 2011). Otonomi daerah, transparansi, dan bantuan keuangan akan menjadi kunci keberhasilan upaya desentralisasi (Green, 2005).

Paradigma pembangunan nasional identik dengan pembangunan ekonomi. Dalam hal ini, tujuan pembangunan nasional adalah mencapai pertumbuhan ekonomi yang setinggitingginya. Pembangunan ekonomi juga dipandang sebagai strategi investasi. Dengan demikian, untuk memenuhi kepentingan tersebut, komunikasi dipandang sebagai instrumen kunci bagi suksesnya usaha pembangunan ekonomi (Rinawati, 2006). Dimensi komunikasi memiliki peran penting dalam mendukung proses pembangunan daerah otonomi baru. Asumsi ini didasari adanya anggapan bahwa komunikasi berfungsi sebagai alat untuk mengkampanyekan gagasan-gagasan pembangunan kepada subjek sasaran yang akan menerima manfaat dari program tersebut. Dibidang penelitian, komunikasi memberikan kontribusinya pada penelitian difusi inovasi, terutama dibidang pertanian kesehatan dan keluarga berencana. Penelitian-penelitian ini telah digunakan hasilnya secara luas oleh pejabat-pejabat pemeritah dalam badan-badan pembangunan (Wardhani, 2002).

Salah satu upaya yang dilakukan oleh pemerintah DOB khususnya di Sulawesi Barat dalam mencapai tujuan pembangunan di daerahnya adalah dengan menerapkan sistem tata kelola pemerintahan yang berasas pada prinsip Good Governance. Penerapan prinsip good governance merupakan upaya untuk menciptakan sistem tata kelola pemerintahan daerah yang efektif dan efisien. Hal ini didukung pula dengan hadirnya Undang-Undang Nomor 23 Tahun 2014 tentang Pemerintahan Daerah.

Namun realitas yang terjadi saat ini, sistem pemerintahan daerah masih dihadapkan pada persoalan ego sektoral. Hal tersebut kemudian berdampak pada proses komunikasi yang terjadi di antara unsur OPD dalam setiap penyelenggaraan sistem tata kelola pemerintahan daerah. Kondisi inilah yang akhirnya dapat mempengaruhi upaya pemerintah daerah dalam mencapai tujuan pembangunan yang diharapkan khususnya dalam hal pengentasan kemiskinan.

Peran komunikasi dalam pembangunan daerah otonomi baru dapat dikaitkan dengan bagaimana konsep dari komunikasi pembangunan itu sendiri. Menurut Srampickal (2006), komunikasi dalam pembangunan merupakan upaya untuk menginformasikan, menciptakan kesadaran, mendidik, dan mencerahkan orang-orang sehingga mereka dapat hidup lebih baik dalam segala hal. Komunikasi pembangunan meliputi tindakan partisipatif untuk belajar dan berbagi kekuasaan: sosial (hak asasi manusia dan munculnya masyarakat sipil), ekonomi (masyarakat egaliter) dan politik (demokratisasi), dalam konteks budaya tertentu.

Berdasarkan fenomena tersebut, penelitian ini kemudian berusaha untuk mengkaji lebih jauh mengenai dinamika dalam proses perencanaan program pembangunan khususnya dalam hal penanggulangan kemiskinan di DOB. Program yang menjadi pembahasan dalam penelitian ini adalah Program Marasa. Program Marasa merupakan program prioritas yang menjadi turunan dari visi misi Gubernur dan Wakil Gubernur Provinsi Sulawesi Barat periode tahun 2017 hingga 2022. Fokus dalam penelitian ini adalah untuk menganalisis 
bagaimana dinamika komunikasi dalam hubungan dan proses koordinasi antar OPD Provinsi Sulawesi Barat dalam mengelola perencanaan program Marasa.

Program Marasa dirumuskan dengan mengintegrasikan beberapa program lintas sektor yang dirumuskan oleh masing-masing Organisasi Perangkat Daerah (OPD) yang terkait. Untuk mendukung pelaksanaan Program Marasa, Pemerintah Sulawesi Barat juga merumuskan program turunan yang diberi nama One Village One Product (OVOP). Tujuan dari OVOP yaitu untuk meningkatkan potensi lokal dari masing-masing desa yang menjadi lokus dalam pelaksanaan Program Marasa.

Pelaksanaan program dan kegiatan Marasa melibatkan sinergitas masing-masing Pemeritah Daerah Kabupaten dari desa yang menjadi lokus program Marasa. Masing-masing OPD Provinsi akan mengintervensi lokus desa sesuai dengan kewenangan serta berdasarkan potensi dan target indikator desa yang telah ditetapkan dalam Program Marasa. Dalam proses perencanaannya, Program Marasa melibatkan OPD lintas sektor yang diintegrasikan ke dalam sekretariat tim koordinasi program Marasa.

Pembentukan tim kordinasi dan sekretariat dalam penyusunan dan pelaksanaan program Marasa telah diatur dalam Keputusan Gubernur Sulawesi Barat Nomor 188.4/303/SULBAR/V/2018 dan Ovop pada Keputusan Gubernur Nomor 188.4/304/SULBAR/V/2018. Total OPD yang terlibat masing-masing 17 OPD untuk untuk sekretariat Desa Marasa dan 21 OPD untuk Sekretariat Ovop. SK tersebut juga mengatur mengenai pembagian peran masing-masing OPD dalam Program Marasa dan Ovop. Tujuan dari penelitian ini adalah mengidentifikasi peran, model, jalur penyebaran informasi serta hambatan komunikasi OPD Provinsi Sulawesi Barat dalam mengelola perencanaan Program Marasa.

\section{METODOLOGI PENELITIAN}

Untuk mengidentifikasi model komunikasi OPD Provinsi Sulawesi Barat dalam perencanaan Program Marasa. Penelitian ini menggunakan teknik pengumpulan data melalui wawancara mendalam dan pengamatan observasi. Selain melalui wawancara mendalam dan pengamatan observasi, data pendukung dalam penelitian ini juga berasal dari sumber dokumen atau arsip. Melalui dokumen atau arsip peneliti juga dapat memperoleh informasi yang terkait dengan proses pengelolaan perencanaan Program Marasa. Jenis penelitian ini merupakan deskriptif kualitatif dengan menggunakan pendekatan studi kasus.

Penelitian ini menjadikan Provinsi Sulawesi Barat sebagai subjek analisis yang akan dikaji. Sumber data primer dari penelitian ini diperoleh dari hasil wawancara dengan subjek penelitian yang terdiri dari OPD Pemerintah Provinsi Sulawesi Barat yang terlibat dalam perencanaan Program Marasa. Informan awal (kunci) dalam penelitian ini terdiri dari Kepala Perencanaan Pembangunan Daerah Provinsi Sulawesi Barat (Bappeda) serta beberapa staf yang bekerja pada Bidang Ekonomi Sosial dan Budaya Badan Bappeda Provinsi Sulawesi Barat. Selain dari Bappeda, data penelitian ini juga diperoleh dari unsur-unsur OPD yang terlibat dalam pengelolaan perencanaan program Marasa. Apabila data yang diperoleh dirasa masih belum cukup, maka data yang ada kemudian dikombinasikan dengan hasil pengamatan (observasi) serta studi literatur pada dokumen dan arsip yang ada di Sulawesi Barat. 
Penelitian ini menggunakan teknik analisis interactive model atau teknik analisis data interaktif. Teknik analisis data interaktif dijalankan dengan cara beberapa tahap. Pertama yaitu proses reduksi data. Pada tahapan ini akan dilakukan pemilihan dan perangkuman data yang muncul pada saat proses pengumpulan data metode wawancara mendalam, observasi dan pengumpulan dokumen arsip. Setelah itu, data yang telah direduksi sebelumnya akan ditampilkan kedalam bentuk teks yang bersifat naratif. Sajian data ini dihadirkan agar peneliti dapat lebih mudah memahami data yang telah ada. Kemudian yang terakhir adalah proses penarikan kesimpulan. Pada tahap ini peneliti akan memverifikasi data yang telah ada lalu kemudian dianalisis dan ditarik kesimpulan berdasarkan fenomena atau peristiwa yang diteliti (Sugiyono, 2016).

\section{HASIL DAN PEMBAHASAN}

\section{Model Komunikasi OPD Provinsi Sulawesi Barat}

Secara umum, dalam lembaga pemerintahan terdapat dua arah arus pertukaran pesan. Yang pertama adalah arah komunikasi ke bawah yang biasanya terjadi pada proses komunikasi pimpinan kepada bawahan atau staf. Jenis pesan yang terdapat ada proses ini berupa instruksi atau perintah yang diberikan pimpinan kepada bawahan. Pesan disampaikan baik secara langsung maupun dengan menggunakan media atau alat komunikasi berupa surat, lembar disposisi dan sebagainya. Kemudian yang kedua adalah komunikasi ke atas atau proses penyampaian pesan dari bawahan/ staf kepada pimpinan. Jenis pesan yang disampaikan umumnya berupa laporan dari hasil pekerjaan yang telah dilakukan oleh bawahan atau staf tersebut.

Di era sekarang ini organisasi dituntut untuk menyiapkan strategi dalam menghadapi dunia yang semakin kompleks. Perlu pemikiran ulang terkait strategi dan konsep mengenai "organiasasi" dan "komunikasi" yang digunakan sebagai pendekatan dalam memahami komunikasi organisasi (Miller, 2006). Karena pada hakikatnya tujuan komunikasi dalam organisasi pemerintah tidak hanya sekedar menyampaikan informasi atau tugas (Silalahi, 2004).

Dalam pengelolaan perencanaan program Marasa, selain dua arah arus komunikasi yang telah dijelaskan di atas, terdapat pula arah arus pertukaran pesan yang mengarah ke samping atau bersifat horizontal. Hal ini terjadi karena pengelolaan perencanaan program Marasa melibatkan banyak sektor di dalamnya. Dari beberapa arah arus komunikasi tersebut, peneliti kemudian membuat gambaran model komunikasi OPD dari proses perencanaan program Marasa seperti pada gambar berikut ini:

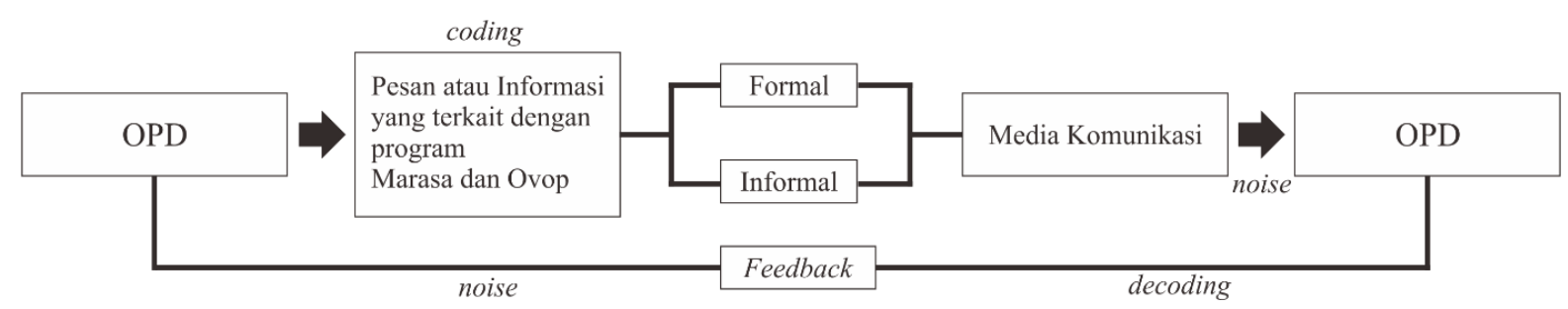

Gambar 1. Model Komunikasi OPD dalam Perencanaan Program Marasa

(Sumber: Hasil analisis dan olah data Peneliti) 
Semua OPD pada model komunikasi dalam pengelolaan perencanaan program Marasa mempunyai potensi yang sama untuk berperan sebagai komunikator (Sender) dan komunikan (receiver). Pesan yang disampaikan umumnya adalah yang terkait dengan perencanaan program Marasa. Pesan tersebut dikirim baik dalam bentuk formal maupun informal melalui berbagai macam media dan saluran komunikasi. Dalam proses penyampaian pesan tersebut, terdapat noise atau hambatan yang dapat menganggu efektifitas dari proses komunikasi yang sedang dilakukan. Oleh karena itu pemilihan media dan saluran komunikasi merupakan proses yang sangat penting untuk diperhatikan. Setelah pesan tersebut diterima, OPD yang berperan sebagai receiver atau komunikan akan memberikan feedback terhadap pesan yang diterimanya.

Sifat terpenting komunikasi organisasi adalah penciptaan pesan, penafsiran, dan penanganan kegiatan anggota organisasi (Ishak, 2012). Karena organisasi merupakan suatu sistem yang menerima dan mengumpulkan berbagai macam informasi dari lingkungannya yang kemudian akan ditafsirkan dan dipahami. Proses ini merupakan bagian dari bagaimana organisasi berupaya untuk memahami dirinya sendiri dan lingkungannya (Weick, 1979).

Model komunikasi dalam perencanaan program Marasa juga menunjukkan hubungan antar jabatan struktur organisasi birokrasi di dalamnya. Hubungan yang bersifat vertikal tersebut merupakan relasi yang terjadi di antara pimpinan dengan staf di bawahnya. Proses ini merupakan salah satu bagian terpenting dalam model komunikasi khususnya pada organisasi yang bersifat formal seperti lembaga pemerintahan. Karena di kebanyakan organisasi, apabila arus informasi ke atas kurang memadai maka akan mengakibatkan pimpinan kekurangan informasi dan kurang mengetahui serta menyadari secara tepat kondisi dan keadaan organisasi pada umumnya dan keadaan bawahan pada khususnya (Silalahi, 2004).

Komponen kunci dalam model komunikasi tersebut menggambarkan bagaimana tindakan komunikatif yang dilakukan oleh masing-masing aktor di dalamnya. Di dalam komponen tersebut terdapat proses transaksi yang dapat memberi tahu informasi apa saja yag dipertukarkan oleh antar OPD di Sulawesi Barat. Transaksi itu sendiri terdiri dari beberapa pesan, yang kemudian dirinci menjadi spesifikasi pertukaran informasi. Spesifikasi ini didasarkan pada jenis dan pola komunikasi yang telah ditentukan, yang membuatnya mudah untuk membangun protokol pesan dengan cara yang terstruktur (Schreiber, 2000).

Lebih lanjut Schreiber (2000) menjelaskan tiga lapisan dalam proses transaksi yang dikonsepsikan ke dalam model komunikasi yang disebut sebagai CommonKADS. Yaitu pertama adalah rencana komunikasi secara keseluruhan yang mengatur dialog antar aktor. Kemudian yang kedua adalah transaksi antar aktor yang menghubungkan dua tugas yang berbeda dari aktor yang terlibat di dalamnya. Dan yang terakhir adalah spesifikasi terkait pertukaran informasi yang merinci struktur pesan yang transaksikan di dalam internal organisasi.

Proses transaksi yang terdapat dalam pengelolaan perencanaan program Marasa pada dasarnya merupakan upaya pemerintah Provinsi Sulawesi Barat dalam merasionalisasikan program yang sedang mereka rencanakan. Menurut Weber (1947) untuk mencapai birokrasi yang rasional, organisasi harus memiliki tiga karakteristik yang terdiri dari otoritas atau 
wewenang, spesialisasi dan peraturan. Ketiga karakteristik ini juga akan sangat mempengaruhi model komunikasi pada organisasi formal seperti lembaga pemerintahan, sehingga kemudian muncul konsep seperti berikut:

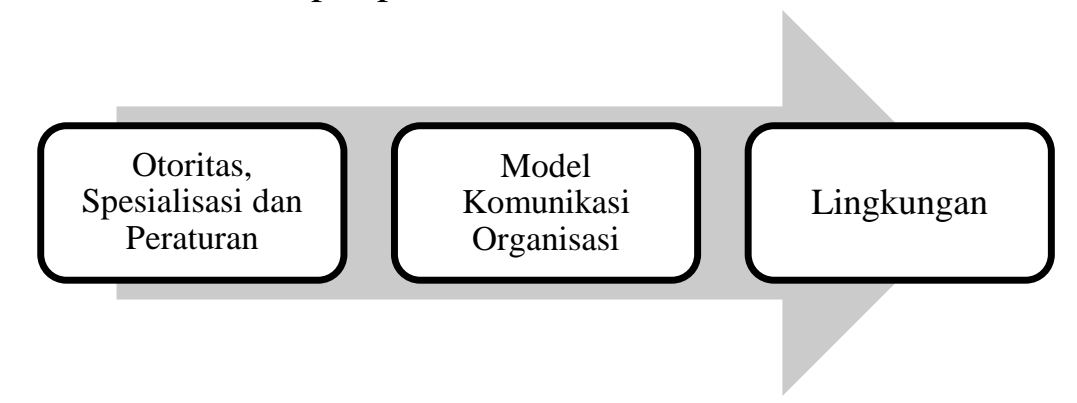

Gambar 2. Rasionalisasi dalam Model Komunikasi Organisasi

(Sumber: Hasil analisis dan olah data peneliti)

Menurut konsepsi Weber (dalam Ritzer, 2014) birokrasi merupakan alat yang paling rasional dalam pelaksanaan otoritas bagi masyarakat. Otoritas dilegitimasi oleh landasanlandasan rasional berupa aturan-aturan formal. Dalam konteks perencanaan program Marasa, landasan rasional tersebut dimanifestasikan dalam Keputusan Gubernur Sulawesi Barat Nomor 188.4/303/SULBAR/V/2018 dan Nomor 188.4/304/SULBAR/V/2018. Keputusan Gubernur tersebut merupakan bentuk pemberian legitimasi terhadap komponen-komponen yang terdapat di dalam struktur pemerintahan di Provinsi Sulawesi Barat. Aturan-aturan inilah yang kemudian mempengaruhi gaya dan model komunikasi organisasi dalam pengelolaan perencanaan program Marasa.

Otoritas dalam birokrasi juga memungkinkan terjadinya pembagian peran dari subsistem-subsistem yang terdapat di dalam struktur pemerintahan Provinsi Sulawesi Barat. Weber (dalam Morissan, 2013) mengungkapkan bahwa spesialisasi merupakan hal penting bagi birokrasi rasional karena secara tegas memberikan prosedur yang jelas terhadap batasan dalam pembagian fungsi dan peran dari suatu organisasi. Aspek ketiga untuk mencapai organisasi yang rasional adalah adanya kebutuhan terkait aturan. Proses koordinasi dalam pengelolaan perencanaan program Marasa dimungkinkan terjadi karena adanya seperangkat aturan yang jelas mengatur terkait pembagian peran dan tugas dari masing-masing OPD di Provinsi Sulawesi Barat.

Ketiga karakterisitik birokrasi rasional tersebut kemudian bekerja pada proses diferensiasi sistem komunikasi pemerintahan Provinsi Sulawesi Barat dalam menghadapi kompleksitas lingkungannya. Ketiga karakteristik tersebut memungkinkan terjadinya proses identifikasi yang membedakan antara sistem dengan lingkungannya. Karena pada dasarnya sistem komunikasi pemerintahan Provinsi Sulawesi Barat dalam pengelolaan perencanaan program Marasa merupakan tipe sistem yang tertutup.

\section{Jalur Penyebaran Informasi Program Marasa}

Hubungan antara OPD Provinsi dengan OPD Kabupaten dan Pemerintah Desa Marasa memiliki struktur jaringan komunikasi yang sangat kompleks. Secara keseluruhan, dalam pola hubungan tersebut terdapat dua alur penyebaran informasi yang terkait dengan 
pengelolaan perencanaan program Marasa. Alur penyebaran informasi tersebut terdiri dari penyebaran informasi melalui jalur formal dan jalur informal. Masing-masing dari pola tersebut kemudian mempengaruhi model dan gaya komunikasi yang dimiliki oleh masingmasing OPD baik pada tingkat Provinsi maupun Kabupaten.

Pada situasi dan kondisi tertentu, hubungan antar jaringan ego OPD Provinsi Sulawesi Barat membentuk dua jalur penyebaran informasi. Jalur penyebaran informasi inilah yang akan mempengaruhi bagaimana hubungan antar OPD di Provinsi Sulawesi Barat dalam mengelola perencanaan program Marasa, baik pada level sistem maupun subsistem. Dua jalur tersebut terdiri dari penyebaran informasi melalui jalur formal dan informal.

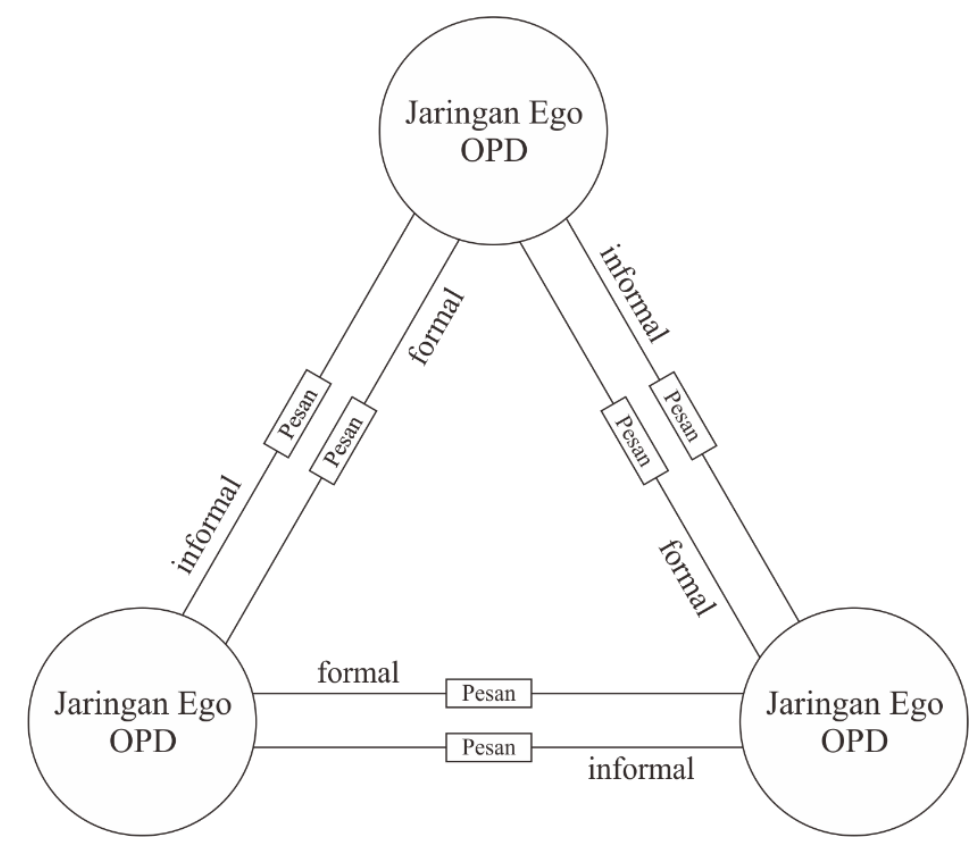

Gambar 3. Jalur Penyebaran Informasi dalam Pengelolaan Perencanaan Program Marasa

(Sumber: Hasil analisis dan olah data Peneliti)

Penyebaran informasi melalui jalur formal dan informal memiliki karakter yang berbeda. Karakter ini dipengaruhi oleh situasi dan kondisi dari aktor atau OPD yang sedang melalukan proses komunikasi. Tidak hanya itu, kedua jalur penyebaran informasi tersebut juga akan berpengaruh terhadap pesan yang dikirim oleh masing-masing OPD yang sedang terlibat dalam perencanaan program Marasa. Sehingga setiap proses pengambilan keputusan akan sangat ditentukan oleh jalur penyebaran informasi yang dipilih oleh masing-masing aktor.

\section{Penyebaran Informasi Jalur Formal Program Marasa}

Penyebaran informasi jalur formal merupakan bentuk penyampaian pesan yang lebih dominan terjadi khususnya pada organisasi yang bersifat formal seperti lembaga pemerintahan. Proses ini identik dengan model komunikasi organisasi klasik yang disampaikan oleh Miller (2006) di mana arah arus komunikasi pada organisasi formal seperti lembaga pemerintahan cenderung bersifat vertikal atau ke bawah. Media atau saluran komunikasi yang digunakan juga lebih banyak dalam bentuk gaya yang formal. 
Pengambilan keputusan dalam pengelolaan perencanaan program Marasa akan sangat dipengaruhi oleh efektifitas dan kelancaran komunikasi dari semua aktor yang terlibat di dalamnya. Sistem komunikasi pada proses penyebaran informasi melalui jalur formal biasanya memiliki garis koordinasi yang secara jelas telah diatur dalam struktur organisasi. Proses penyebaran informasi melalui jalur formal pada lembaga pemerintahan umumnya dilakukan dengan dua cara, yaitu dengan komunikasi langsung (face to face) dan menggunakan media komunikasi seperti memo, lembar disposisi dan mekanisme persuratan lainnya. Hal ini pun juga dilakukan dalam perencanaan program Marasa dan Ovop.

Jenis komunikasi formal seperti yang diungkapkan oleh Mulyana (2005) adalah komunikasi yang bersifat horizontal atau dilakukan oleh pihak yang memiliki kedudukan yang sama, vertikal atas ke bawah atau komunikasi dari tingkat satu ke tingkat yang lainnya, serta diagonal atau proses komunikasi yang terjadi di antara dua pihak yang berada pada jalur struktur yang berbeda. Interaksi dengan model formal biasanya tidak dilakukan dengan intensitas yang tinggi. Hal ini diakibatkan oleh rumitnya proses yang harus dilalui untuk mempersiapkan dan mengadakan rapat-rapat koordinasi yang melibatkan banyak OPD. Mulai dari kesiapan sumber daya manusia, anggaran, waktu hingga persoalan geografis yang juga menyulitkan diadakannya pertemuan yang secara khusus membahas perencanaan program Marasa.

Bentuk penyebaran informasi melalui jalur formal pada perencanaan program Marasa dilakukan dalam berbagai macam cara. Yang pertama adalah rapat koordinasi dan asistensi program masing-masing OPD. Pada tahapan ini, semua OPD yang terlibat dalam perencanaan program Marasa akan diundang oleh Bappeda Provinsi Sulawesi Barat untuk membahas terkait sinkronisasi program OPD yang dapat mendukung Program Marasa. Kegiatan ini intens dilakukan sejak pertama kali program Marasa dirumuskan. Biasanya Bappeda Provinsi Sulawesi Barat mengadakan kegiatan tersebut maksimal sekali dalam sebulan.

Kegiatan koordinasi tersebut tidak hanya dilakukan oleh OPD Provinsi, namun juga turut melibatkan OPD pada tingkat Kabupaten. Di mana OPD Provinsi maupun Kabupaten akan melakukan perjalanan dinas untuk melakukan koordinasi terkait perencanaan program Marasa. Rapat koordinasi dan asistensi program ini merupakan penyebaran informasi jalur formal yang bersifat face to face atau komunikasi langsung.

Selain dengan metode komunikasi langsung, penyebaran informasi program Marasa melalui jalur formal juga menggunakan saluran komunikasi yang memanfaatkan media cetak seperti surat. Pada proses ini, komunikasi yang dominan terjadi adalah model komunikasi yang bersifat diagonal. Yaitu melibatkan aktor yang berada dalam struktural organisasi yang berbeda atau lintas sektor OPD. Jenis pesan yang terdapat pada saluran komunikasi ini umumnya berupa teks atau non-verbal.

Efektifitas komunikasi pada proses penyebaran informasi melalui jalur formal dengan menggunakan media surat akan sangat dipengaruhi oleh aktor yang berperan sebagai pengirim dan penerima pesan. Aktor tersebut bertugas untuk memberikan sandi (encode) pada pesan yang akan disampaikan ke dalam bentuk teks, grafik maupun data-data yang terkait dengan perencanaan program Marasa. Setalah pesan tersebut disandi (encode), aktor yang bertugas menerima pesan (receiver) akan memberikan interpretasi (decoding) terhadap 
pesan yang diterimanya. Dalam konteks ini, setiap aktor yang menerima pesan melalui media surat akan menginterpretasikan (decoding) pesan yang diterima kemudian memberikan respon atas pesan tersebut baik melalui saluran yang sama maupun dengan saluran yang berbeda. Kelemahan pada saluran ini adalah setiap penerima pesan tidak memiliki kesempatan untuk merespon pesan yang diterima secara langsung.

Pemaknaan atas pesan atau informasi tentunya akan sangat berpengaruh terhadap efektifitas komunikasi dalam perencanaan program yang sedang dilakukan. Noise atau gangguan pada tahapan ini perlu dihindari dan diminimalisir sebaik mungkin. Hal ini berkaitan dengan proses sinkronisasi program kegiatan pada program Marasa yang membutuhkan keakuratan informasi yang tepat. Sehingga program yang telah direncanakan akan tepat sasaran sesuai dengan tujuan yang diinginkan oleh masing-masing OPD.

Elemen utama dalam jaringan komunikasi adalah relasi antar aktor yang terdapat di dalamnya dan dari relasi itu pula dapat diperoleh bagaimana sebuah informasi mengalir dalam suatu jaringan komunikasi (Wardyaningrum, 2016). Karena pada dasarnya organisasi pemerintah tidak dapat melaksanakan fungsinya dengan baik tanpa adanya proses komunikasi di dalamnya (Beach, 1975). Proses inilah yang kemudian membentuk sistem komunikasi pemerintah di Provinsi sulawesi Barat.

Dalam perencanaan program Marasa, tidak semua OPD yang terdapat dalam struktur pemerintahan Provinsi Sulawesi Barat dapat dilibatkan. Hal ini terjadi karena struktur pada organisasi sangat kompleks sehingga hanya beberapa OPD yang dilibatkan secara langsung dalam perencanaan program Marasa. Telah dijelaskan pada bab sebelumnya di mana OPD yang secara aktif terlibat dalam perencanaan program Marasa dan Ovop hanya 15 OPD. Mekanisme tersebut terjadi karena semakin tinggi kompleksitas maka semakin meningkat pula tingat selektivitas (Hanitzch, 2001). Sehingga dicari jalur efektif yang dapat menghubungkan keseluruhan dari sistem komunikasi pemerintah Sulawesi Barat dengan cara yang selektif. Yaitu dengan mereduksi jumlah subsistem yang terlibat di dalamnya melalui cara formal berupa pembuatan SK Program Marasa dan Ovop.

\section{Penyebaran Informasi Jalur Informal Program Marasa}

Selain penyebaran informasi dengan jalur formal, proses perencanaan program Marasa juga menggunakan pola penyebaran informasi dengan jalur informal. Hal ini dilakukan apabila terjadi kendala pada saat proses komunikasi antar OPD yang bersifat formal. Penyebaran informasi dengan jalur informal terjadi seiring dengan tingginya intensitas interaksi yang terjadi di antara OPD yang terlibat dalam pengelolaan perencanaan program Marasa.

Pendekatan komunikasi informal tidak hanya sekedar mendekatkan hubungan antar individu maupun OPD, namun turut pula membentuk klik atau jalinan pertemanan baru di luar organisasi. Dalam konteks organisasi yang bersifat formal, pola penyebaran informasi melalui pendekatan komunikasi informal justru lebih efektif bila dibandingkan dengan pendekatan komunikasi formal.

"Kadang lebih gampang menghubungi OPD dengan jalur pertemanan daripada dengan cara formal yang menggunakan surat. Data yang kita butuhkan akan lebih 
cepat diberikan kalau dihubungi via telepon atau WA, kalau pake surat bisa sampai sebulan baru datang itu data yang kita minta" (Muhammad Saleh, 2018)

Seperti yang diungkapkan oleh Muhammad Saleh sebagai salah satu aktor yang banyak terlibat dalam pengelolaan perencanaan program Marasa. Penyebaran informasi melalui jalur informal justru lebih efektif dalam berkoordinasi dengan OPD-OPD terkait dibandingkan dengan menggunakan cara yang bersifat formal. Kondisi tersebut hanya bisa tercapai apabila terjadi interaksi interpersonal secara berkelanjutan antara dua pihak baik individu maupun OPD. Interaksi interpersonal melalui pendekatan komunikasi informal juga mampu memudahkan proses pertukaran informasi antar OPD. Adanya bentuk komunikasi informal dalam jaringan komunikasi antar OPD di Provinsi Sulawesi Barat menjadi penting untuk dianalisis khususnya dalam proses komunikasi organisasi yang berbentuk formal.

Media komunikasi yang umum digunakan dalam proses penyebaran informasi jalur informal adalah melalui pemanfaatan teknologi informasi atau media baru seperti telepon, aplikasi whatsapp dan email. Seperti yang dijelaskan pada pembahasan pada sub bab sebelumnya bahwa pertemuan langsung umumnya lebih didominasi oleh penyebaran informasi melalui jalur formal. Misalnya seperti rapat koordinasi, proses asistensi program dan sebagainya. Namun bentuk komunikasi langsung secara face to face juga tidak menutup kemungkinan terjadinya proses pertukaran informasi melalui jalur informal. Hal ini terjadi berkat adanya hubungan interpersonal antara aktor yang terlibat di dalamnya.

Jenis informasi yang biasanya disebar melalui jalur informal berupa pertukaran data yang dibutuhkan oleh OPD terkait. Kelompok-kelompok informal yang terbentuk dari proses ini diisi oleh OPD-OPD yang memiliki tugas pokok dan fungsi yang sama dalam satu bidang. Misalnya Dinas Pertanian, Dinas Ketahanan Pangan dan Dinas Perdagangan, Industri, Koperasi dan UKM yang sama-sama membahas terkait ketersiadaan pangan di lokus desa Marasa. Kemudian Dinas Energi Sumber Daya Mineral dan Dinas Komunikasi, Informatika, Persandian dan Statistik yang mempunyai tugas dalam mendukung ketersediaan energi dan jaringan telekomunikasi di desa Marasa.

Proses pertukaran informasi melalui jalur informal juga melibatkan pembagian peran pada masing-masing OPD. Relasi yang tercipta antara Bappeda dengan OPD bertransformasi menjadi bridge dalam struktur jaringan komunikasi OPD Provinsi Sulawesi Barat. Pesan informal yang diterima oleh Bappeda dari OPD akan diteruskan kepada OPD yang lainnya juga dengan menggunakan pendekatan jalur komunikasi informal. Begitu pun dengan beberapa OPD lainnya yang terlibat dalam perencanaan program Marasa. Dari proses tersebut dapat dilihat bahwa Bappeda juga berperan sebagai brokerage atporiat.

Efektivitas komunikasi secara tidak langsung akan sangat dipengaruhi oleh strategi komunikasi yang diterapkan. Penyebaran informasi melalui jalur informal merupakan bentuk strategi komunikasi yang digunakan untuk memudahkan proses koordinasi antar OPD yang berbentuk formal. Widiyahseno (2018) mengungkapkan bahwa, inovasi dalam pemerintahan tidak selalu berbicara mengenai kebijakan, namun juga mengenai bagaimana hubungan antara inovator (pemimpin) dengan subordinat yang ada di bawahnya serta dengan berbagai pihak penting lainnya.

Penyebaran informasi melalui jalur informal adalah salah satu bentuk inovasi yang bertujuan untuk membongkar kakunya struktur yang terdapat dalam organisasi formal seperti 
lembaga pemerintahan. Aktor utama yang menjadi inisiator dalam membangun proses pertukaran informasi melalui jalur informal ini ialah Bappeda Provinsi Sulawesi Barat. Hal ini bisa terjadi karena Bappeda memiliki peran sentral sebagai opinion leader dalam jaringan komunikasi antar OPD Provinsi Sulawesi Barat.

Proses pertukaran informasi melalui jalur informal juga terbentuk karena adanya faktor kepentingan dari masing-masing aktor yang terlibat di dalamnya. Kepentingan ini memunculkan persamaan-persamaan tertentu di antara para aktor (homofili). Dalam proses ini, masing-masing aktor memiliki peran yang berbeda-beda. Mulai dari opinion leader, gate keeper, liaison hingga broker yang menghubungkan satu aktor ke aktor yang lainnya. Peran tersebut tidak mutlak hanya dimainkan oleh satu aktor saja, namun masing-masing aktor dapat memerankan peran-peran tersebut. Inilah yang membedakan karakteristik pertukaran informasi melalui jalur informal dengan formal, yaitu perbedaan pada pembagian peran yang lebih bersifat dinamis.

Kelemahan yang terdapat pada proses pertukaran informasi melalui jalur informal yaitu potensi terjadinya Isolate cenderung tinggi. Hal ini diakibatkan karena pertukaran informasi melalui jalur informal hanya dapat dilakukan oleh OPD maupun aktor yang mereprenstasikan OPD harus memiliki hubungan interpersonal yang dekat. Sehingga aktor yang berada di luar circle akan sulit bergabung ke dalam jaringan komunikasi tersebut. Selain aktor yang terisolasi dari circle, proses ini juga memunculkan aktor yang berperan sebagai star. Star yaitu aktor yang sangat intens dihubungi oleh berbagai pihak yang membutuhkan informasi terkait pengelolaan program Marasa. Peran ini dimainkan aktor yang memiliki tugas untuk mengumpulkan informasi dan menyusun dokumen perencanaan program Marasa.

Dalam suatu jaringan, selalu ada anggota atau aktor yang memiliki popularitas lebih dibandingkan dengan anggota yang lainnya (Gani dan Unde, 2016). Aktor-aktor inilah yang paling memungkinan dalam membangun relasi dan melakukan proses penyebaran informasi melalui jalur informal. Aktor tersebut tidak selalu direprensetasikan oleh pimpinan dalam hal ini adalah pejabat eselon satu pada level struktur pemerintahan di Sulawesi Barat. Namun pejabat eselon tiga, eselon empat hingga staf juga mampu menjadi aktor yang populer di antara aktor yang lainnya.

Penyebaran informasi melalui jalur informal juga merupakan upaya dari sistem komunikasi pemerintah Provinsi Sulawesi barat dalam mereduksi kompleksitas lingkungannya. Karena sistem tidak boleh lebih kompleks dari lingkungannya, sistem harus mampu membedakan diri dengan lingkungannya dan mampu mereduksi kompleksitas dalam dirinya (Handaka et all., 2017). Sama seperti proses penyebaran informasi melalui jalur formal, keberadaan aktor-aktor tertentu yang memiliki popularitas lebih dibandingkan dengan aktor lainnya merupakan bentuk dari sistem yang terdiferensiasi. Cara ini adalah bagaimana sistem komunikasi pemerintah Provinsi Sulawesi Barat beradaptasi dengan komplesitas lingkungannya.

\section{Hambatan Komunikasi OPD Provinsi Sulawesi Barat}

Kegagalan komunikasi dalam suatu organisasi terjadi karena organisasi memiliki karakteristik yang dinamis, dimana organisasi merupakan suatu sistem terbuka yang terus 
menerus akan mengalami perubahan karena dihadapkan oleh tantangan dari lingkungan sekitarnya sehingga memerlukan penyesuaian atas hal tersebut (Fahrihanto, 2011). Kompleksitas inilah yang akan senantiasa dihadapi oleh sistem komunikasi OPD Provinsi Sulawesi Barat dalam kaitannya dengan perencanaan program Marasa.

Ada beberapa hal yang biasanya menghambat proses komunikasi organisasi, mulai dari faktor gaya kepemimpinan hingga cara penyampaian pesan yang turut mempengaruhi efektifitas komunikasi organisasi. Sama halnya yang terjadi pada proses koordinasi antar OPD di Provinsi Sulawesi Barat, hambatan-hambatan komunikasi juga ditemui dalam proses tersebut. Seperti yang disampaikan oleh masing-masing OPD dalam kuisioner terbuka yang disebar oleh peneliti, setiap informan yang mewakili setiap OPD menyampaikan hambatan apa saja yang mereka temui dalam pengelolaan perencanaan program Marasa.

Dinas Kesehatan mengungkapkan bahwa, setiap OPD sudah memiliki tugas pokok dan fungsi masing-masing. Konsekuensi dari hal tersebut adalah, setiap OPD telah memiliki kegiatan dan pekerjaan masing-masing. Sehingga sulit untuk membagi waktu antara pekerjaan utama dengan pekerjaan untuk membantu penyusunan program Marasa. Selain itu, ketiadaan petunjuk teknis terkait program Marasa juga menyulitkan Dinas Kesehatan dalam menyusun program mana saja yang akan mendukung program prioritas tersebut.

Begitu pula dengan Dinas Pendidikan dan Kebudayaan, mereka menyampaikan bahwa mensinkronkan program kerja dari masing-masing OPD ke dalam program Marasa adalah pekerjaan yang sulit. Terlebih belum adanya petunjuk atau pedoman untuk perencanaan program Marasa. Senada dengan Dinas Pendidikan dan Kebudayaan, Dinas Pemberdayaan Masyarakat dan Desa juga menyampaikan bahwa kesulitan lain dalam pengelolaan perencanaan program Marasa adalah penentuan lokus serta interpretasi terhadap indikatorindikator yang ingin dicapai. Beberapa kendala yang disampaikan oleh OPD tersebut berpotensi untuk menimbulkan adanya perbedaan persepsi dan pemikiran terhadap program yang sedang direncanakan. Sehinggat juga akan turut berpengaruh terhadap proses komunikasi antar OPD.

Kunci utama dalam proses komunikasi ialah bagaimana pesan yang disampaikan oleh komunikator dapat diterima secara lengkap dan dipahami serta dimaknai secara tepat oleh komunikan. Adanya perbedaan persepsi antara komunikator dan komunikan tentu akan mendistorsi proses komunikasi yang terjadi di antara keduanya. Akhirnya tujuan yang ingin dicapai dari komunikasi tersebut tidak tercapai. Hal inilah yang disampaikan oleh Dinas Perpustakaan dan Kearsipan Daerah. Menurut mereka, internalisasi program Marasa baik pada Provinsi maupun Kabupaten belum berjalan optimal. Selain itu, pola pembagian peran antara Pemerintah Provinsi, Kabupaten dan Desa juga dianggap masih belum jelas.

Dinas Kelautan dan Perikanan serta Dinas Sosial juga menyampaikan pendapat yang sama dengan Dinas Perpustakaan dan Kearsipan Daerah, dimana koordinasi dengan pihakpihak yang terkait masih belum berjalan maksimal. Terutama dalam pengumpulan data yang akan mendukung program Marasa. Akibat dari persoalan ini, Dinas Tenaga Kerja mengungkapkan bahwa OPD kesulitan untuk menyesuaikan program yang mereka miliki dengan program OPD lainnya.

Desa yang menjadi lokus dari program Marasa sebelumnya ditentukan sendiri oleh masing-masing Kabupaten melalui Dinas Pemberdayaan Masyarakat dan Desa serta Badan 
Perencanaan Pembangunan Daerah. OPD Provinsi dalam hal ini hanya sekedar diberitahu terkait dengan desa-desa mana saja yang akan disasar oleh program yang mereka susun. Akibatnya, target desa yang telah ditentukan tersebut ternyata tidak sesuai dengan desa-desa yang sebelumnya sudah ditentukan dalam rencana kerja masing-masing OPD. Sehingga semua OPD perlu menyesuaikan kembali program yang telah mereka susun di dalam rencana kerja dengan program Marasa.

Hampir semua OPD yang terlibat dalam pengelolaan perencanaan program Marasa menganggap keterbatasan anggaran sebagai persoalan utama. Meskipun Bappeda Provinsi Sulawesi Barat telah menyampaikan bahwa akan ada alokasi khusus untuk mendukung program Marasa. Perbedaan persepsi tersebut terjadi karena adanya perbedaan kepentingan di antara Bappeda dengan OPD yang terkait. Perbedaan kepentingan tersebut juga berkaitan dengan relasi kuasa yang terdapat di dalam lingkungan birokrasi. Terdapat perbedaan agenda di antara masing-masing OPD. Hal ini berkaitan dengan adanya perbedaan tugas pokok dan fungsi dari setiap OPD.

Relasi antar OPD dalam pengelolaan perencanaan program Marasa kemudian hanya sekedar menjadi persoalan lobi dan negosiasi anggaran. Akibat dari hal tersebut, proses komunikasi OPD akan sulit untuk mengedepankan konsensus bersama sehingga substansi dari penyusunan program justru tidak tercapai. Hambatan lain yang juga ditemukan adalah porsi keterlibatan dari masing-masing pejabat Eselon yang berbeda-beda dari masing-masing OPD. Dalam praktiknya, perencanaan program Marasa lebih banyak melibatkan pejabat Eselon III dan Eselon IV. Pejabat Eselon III terdiri dari Kepala Bagian atau Kepala Badan, sementara pejabat Eselon IV terdiri dari Kepala Sub Bagian atau Kepala Seksi. Bahkan beberapa OPD yang hanya menugaskan staf untuk menghadiri setiap rapat koordinasi perencanaan program Marasa.

Persoalan di atas berimbas pada praktek pertukaran informasi dari masing-masing individu yang ditugaskan oleh setiap OPD. Jenjang komunikasi dalam penyampaian pesan dan pertukaran informasi dari masing-masing OPD akan menjadi berbeda-beda akibat dari adanya perbedaan individu yang terlibat. Hal tersebut akan menjadi semakin rumit dan kompleks ketika terjadi mutasi jabatan yang mengakibatkan tergantinya posisi dari masingmasing individu. Seperti yang terjadi di Sulawesi Barat, ketika pada tanggal 18 Mei 2018 terjadi mutasi jabatan secara besar-besaran. Gubernur Sulawesi Barat pada saat itu mengganti posisi 14 pejabat tinggi Eselon II, 110 pejabat Eselon III dan 381 pejabat Eselon IV.

Hampir semua pejabat Eselon III dan IV yang terkena mutasi jabatan merupakan pejabat yang bekerja pada bagian perencanaan program. Hal ini kemudian mengakibatkan terputusnya informasi terkait perencanaan program Marasa. Pejabat yang terkena mutasi justru tidak menyampaikan atau melanjutkan informasi yang mereka peroleh kepada pejabat baru yang menggantikan posisi mereka. Sehingga pejabat-pejabat yang baru menempati posisinya kemudian belum mengetahui informasi mengenai program Marasa.

Kondisi yang dihadapi dalam pengelolaan perencanaan program Marasa juga menunjukkan bahwa perubahan lingkungan dapat membawa dampak yang cukup besar. Meskipun lingkungan birokrasi merupakan mekanisme kerja yang memiliki keteraturan dalam menjalankan organisasi formal seperti lembaga pemerintahan. Namun realitas yang 
terjadi justru menunjukkan bahwa birokrasi juga tidak terlepas dari kelemahan. Seperti yang disampaikan oleh Susanto (2010) bahwa dalam dinamika perubahan, birokrasi seringkali belum mampu mengantisipasi perubahan yang ada akibat sifatnya yang sangat konvensional.

Proses pertukaran informasi antar OPD dalam pengelolaan perencanaan program Marasa menjadi sulit akibat adanya sturktur hierarki yang kuat. Pola komunikasi yang terjadi cenderung linier dan kurang variatif akibat adanya berbagai macam aturan organisasi yang bersifat wajib dan kaku. Selain itu, terdapat potensi manipulasi dalam proses penyampaian pesan dan informasi. Hal ini terjadi karena setiap OPD tidak terlepas dari kepentingan individual masing-masing anggotanya. Tindakan tersebut merupakan bentuk perilaku organisasi yang lazim terjadi pada lembaga pemerintahan.

\section{PENUTUP}

Persoalan ego sektoral yang selama ini dihadapi oleh lembaga pemerintahan daerah jika ditinjau dari perspektif komunikasi terjadi karena kesalahan dalam pendekatan gaya komunikasi, pemilihan saluran dan media komunikasi. Hal ini terlihat dari bagaimana pendekatan komunikasi yang bersifat formal dalam sistem komunikasi pemerintahan OPD Provinsi Sulawesi Barat justru menimbulkan berbagai macam persoalan. Mulai dari sulitnya koordinasi antar lintas sektor, keterbatasan penciptaan ruang komunikasi serta berbagai macam persoalan ego sektoral lainnya.

Aktor-aktor yang terdapat di Provinsi Sulawesi Barat kemudian mensiasati hal tersebut dengan menggunakan pendekatan gaya komunikasi yang bersifat informal. Pendekatan ini sedikit banyak mampu mengurangi berbagai macam hambatan yang diakibatkan oleh proses penyebaran informasi yang bersifat formal. Penyebaran informasi melalui jalur informal juga semakin didukung dengan hadirnya media baru seperti aplikasi Whatsapp dan Email. Media baru tersebut mampu memberikan alternatif media komunikasi bagi aktor atau OPD yang terlibat dalam pengelolaan perencanaan program Marasa. Sehingga keterbatasan yang terdapat dalam proses penyebaran informasi melalui jalur formal dapat sedikit dikurangi melalui pemanfaatan media baru.

Penelitian ini secara umum memberikan gambaran terkait dengan bagaimana dinamika komunikasi yang terjadi pada lembaga pemerintahan khususnya dalam proses perencanaan dan perumusan suatu program. Komunikasi merupakan salah satu elemen penting dalam setiap proses pengambilan keputusan di organisasi pemerintahan. Agar komunikasi yang dijalankan pemerintah dapat berjalan efektif, maka organisasi formal seperti lembaga pemerintah perlu mengubah gaya dan model komunikasi yang mereka gunakan. Proses perencanaan pesan, pemilihan saluran dan media komunikasi serta pendekatan dan gaya komunikasi merupakan beberapa hal penting yang perlu diperhatikan.

Beberapa temuan dalam penelitian ini telah menunjukkan bahwa pemerintah perlu mendesain strategi komunikasi yang mampu meningkatkan efektifitas proses koordinasi antar lembaga pemerintahan. Saran khusus yang ingin disampaikan dalam penelitian ini yaitu pentingnya pelaksanaan audit komunikasi bagi lembaga pemerintahan.

Audit komunikasi merupakan proses awal yang dapat digunakan untuk mendesain strategi komunikasi bagi organisasi pemerintahan. Audit komunikasi dapat dilakukan dengan berbagai macam pendekatan, salah satunya melalui pendekatan analisis jaringan komunikasi. 
Pendekatan jaringan komunikasi digunakan untuk mengidentifikasi bagaimana proses penyebaran informasi dalam suatu organisasi. Analisis jaringan komunikasi tidak hanya mampu melihat sejauh mana dinamika komunikasi yang terjadi dalam lembaga pemetintahan. Namun juga mampu mengindentifikasi aktor-aktor kunci serta hambatan komunikasi yang terdapat di dalam lembaga tersebut.

\section{REFERENSI}

Brady, Danielle; Webb, Naomi. (2013). Communicating bushfire safety in Australia: the challenge for government of increasing community participation. Asia Pacific media educator, 23(2), 351-365.

Ahmad, Irdam. (2011). Disparitas Hasil Pembangunan Kabupaten/Kota sebelum dan sesudah Otonomi daerah. Jurnal Ilmu Administrasi Negara, 11(2), 56 -166.

Beach, Dale S. (1975). Personel: The Management of People at Work; third edition. New York: MacMillan Publishing Co, Inc

Cassells, Rebecca. (2014). Revisting The Impact of Consumption Growth and Inequality on Poverty in Indonesia During Decentralisation. Bulletin of Indonesian Economic Studies, 50(3), 461-482.

Gani, N. S., \& Unde, A. A. (2017). Begal dan Keresahan Masyarakat (Jaringan Komunikasi Kelompok Anarkis di Kota Makassar). KAREBA: Jurnal Ilmu Komunikasi, 5(2), 286298.

Green, K. (2005). Decentralization and good governance: The case of Indonesia. Available at SSRN 1493345.

Handaka, Tatag dan Hermin Indah Wahyuni. (2017). Interlasi Subsistem Komunikasi Pemerintah dalam Pengembangan Kambing Kaligesing di Purworejo. Jurnal Ilmu Komunikasi, 14(2), 203-220.

Hanitzsch, T. (2001). Teori Sistem Sosial dan Paradigma Konstruktivisme: Tantangan Keilmuan Jurnalistik di Era Informasi. Mediator: Jurnal Komunikasi, 2(2), 217-229.

Huraerah, Abu. (2013. Strategi Kebijakan Penanggulangan Kemiskinan di Indonesia. Jurnal Ilmu Kesejahteraan Sosial, 12(1).

Ishak, Aswad. (2012). Peran Public Relation dalam Komunikasi Organisasi. Jurnal Komunikasi ASPIKOM, 1(4), 373-380.

Miller, Katherine. (2006). Organizational Communication: Approaches and Processes. Boston: Wadsworth Cengage Learning

Morissan. (2013). Teori Komunikasi: Individu hingga Massa. Jakarta: Kencana

Mulyana, Deddy. (2005). Ilmu Komunikasi: Suatu Pengantar. Bandung: Rosdakarya.

Nawawi, Juanda. (2015). Analisis Hubungan DPRD dan Pemerintah Daerah dalam Pembuatan Kebijakan Kemiskinan di Provini Sulawesi Barat. Government: Jurnal Ilmu Pemerintahan, 8(1), 27-42.

Rinawati, Rini. (2006). Komunikasi dan Pembangunan Partisipatif. MediaTor, 7(2), 175184.

Ritzer, George dan Douglas J. Goodman. (2014). Teori Sosiologi: Dari Sosiologi Klasik sampai Perkembangan Terakhir Postmodern. Yogyakarta: Pustaka Pelajar 
Suharto, Edi. (2009). Menengok Kriteria Kemiskinan di Indonesia: Menimbang Indikator Kemiskinan Berbasis Hak. Jurnal Analisis Sosial, 14(2).

Schreiber Guus, et al. (2000). Knowledge Engineering and Management: The CommondKADS Methodology. Cambridge: The MIT Press

Silalahi, Ulber. (2004). Komunikasi Pemerintahan: Mengirim dan Menerima Informasi Tugas dan Infomrasi Publik. Jurnal Administrasi Publik, (3)1.

Srampickal S.J. Jacob. (2006). Development and Participatory Communication. Communication Research Trends, 25(2).

Susanto, Eko Harry. (2010). Kelambanan Reformasi Birokrasi dan Pola Komunikasi Lembaga Pemerintah. Jurnal Aspikom, 1(1), 1-124.

Sugiyono. 2016. Metode Penelitian: Kuantitatif, Kualitatif dan R\&D. Bandung: Alfabeta

Wardhani, Andy Corry. (2002). Kontribusi Komunikasi pada Teori Pembangunan. MediaTor, 3(2), 260-266.

Wardyaningrum, D. (2016). Modal sosial inklusif dalam jaringan Komunikasi bencana. Jurnal Aspikom, 3(1), 33-55.

Weber, Max. (1947). The Theory of Social and Economic Organization. Translated by A.M Henderson and Talcott Parsons. New York: Oxford University Press.

Weick, Karl. (1979). The Social Psychology of Organizing 2nd ed. Addison-Wesley 